\title{
Reproductive activity and recruitment of the yellow-mandi Pimelodus maculatus (Teleostei: Pimelodidae) in the Igarapava Reservoir, Grande River, Southeast Brazil
}

\author{
Bruno Pereira Maia*, Sandra Maria Franco Ribeiro*, Paula Maciel Bizzotto*, \\ Volney Vono** and Hugo Pereira Godinho****
}

The catfish yellow-mandi, Pimelodus maculatus, is a valuable sporting and commercial fish of inland waters of Southeast Brazil including Igarapava Reservoir. It is a short-distance migrant that needs shorter stretches of free-flowing river to spawn compared to other Neotropical migrants. Igarapava Reservoir is one the 13 hydroelectric reservoirs, arranged in a cascade fashion, impounding the 1,300 km-long Grande River, SE Brazil. In this paper, we examined reproductive features and recruitment of the yellow-mandi in Igarapava Reservoir. We also evaluated the role of the Igarapava Fish Ladder (IFL) built around Igarapava Dam on the sustainability of its fisheries. Female adult yellow-mandis that were gill netted (nets of 8-20 cm stretchmesh) during the reproductive season of 2002/2003, showed adequate ovarian development, indicated by the gonadosomatic index (12.9 \pm 2.1 , at mature stage) and absolute fecundity $(413,794 \pm 206,259$; range $=125,601-742,026)$, which were higher than those found in the literature. Postovulatory follicles present in ovarian tissue of $32 \%$ of the females examined showed that they possibly could have spawned in the reservoir area. Gill nets of 3-5 cm stretch-mesh aimed at capturing juvenile yellow-mandi were unproductive. These results indicated that Igarapava Reservoir and its reduced catchment area did not provide adequate conditions for recruitment of the yellow-mandi. This fish, the most abundant in the IFL, and those reaching the reservoir tended to remain there since no upstream passage mechanism is present. Thus, the IFL apparently was responsible for maintaining the Igarapava Reservoir stock of yellow-mandi.

O mandi-amarelo, Pimelodus maculatus, é um peixe importante nas pescarias comercial e desportiva de águas continentais do Sudeste do Brasil, incluindo o reservatório de Igarapava. Ele é um migrador de curta distância que necessita de segmentos mais curtos de fluxos livres de rios para desovar do que outros migradores. O reservatório de Igarapava é um dos 13 reservatórios hidrelétricos, dispostos em cascata, que fragmentaram os $1.300 \mathrm{~km}$ do rio Grande, no sudeste do Brasil. Neste trabalho, examinamos aspectos reprodutivos e o recrutamento do mandi-amarelo no reservatório de Igarapava. Avaliamos também o papel da escada de peixes, construída em torno da barragem de Igarapava, na sustentabilidade da pesca desse peixe no respectivo reservatório. Fêmeas de mandis-amarelos adultas, capturadas durante o período reprodutivo, com redes de emalhar (tamanho de malha entre 8 e $20 \mathrm{~cm}$, medido entre nós opostos), exibiram adequado desenvolvimento ovariano, indicado pelo índice gonadossomático $(12,9 \pm 2,1$, no estádio maduro $)$ e fecundidade absoluta (413.794 \pm 206.259 ; amplitude $=125.601$ 742.026). Esses valores foram mais altos do que os registrados na literatura. Folículos pós-ovulatórios, presentes no ovário de $32 \%$ das fêmeas examinadas indicaram que, possivelmente, elas poderiam ter desovado no reservatório. Redes de emalhar de 3-5 cm de malha (medida entre nós opostos), colocadas com o objetivo de se capturar juvenis, mostraram-se improdutivas. Esses resultados indicaram que o reservatório de Igarapava e sua reduzida bacia hidrográfica não teriam condições adequadas para o recrutamento do mandi-amarelo. Esta é a espécie mais abundante na escada de peixes de Igarapava e os indivíduos que atingem o reservatório de Igarapava tenderiam a permanecer ali em razão da inexistência de mecanismo de passagem para montante. Portanto, a passagem de mandis-amarelos pela escada foi, aparentemente, responsável pela manutenção de seu estoque no reservatório de Igarapava.

Key words: Reservoir fisheries, Igarapava fish ladder, Stages of gonadal maturation, Fecundity.

\footnotetext{
*Programa de Pós-gradução em Zoologia de Vertebrados, Pontifícia Universidade Católica de Minas Gerais, Av. Dom José Gaspar, 500, 30535-610 Belo Horizonte, MG, Brazil. brunopmaia@terra.com.br (BPM), bizzottopaula@yahoo.com.br (PMB)

**Centro de Transposição de Peixes, Universidade Federal de Minas Gerais, Av. Antônio Carlos, 6627, 31270-901 Belo Horizonte, MG, Brazil.lagovono@netuno.lcc.ufmg.br(VV)

***Present address: Rua João A. Cardoso, 192, 31310-390 Belo Horizonte, MG, Brazil. hgodinho@ufmg.br (HPG)
} 


\section{Introduction}

Migratory fishes are an important component of Neotropical freshwater fisheries (Carolsfeld \& Harvey, 2003). In the last decades, they have been submitted to severe constraints by hydroelectric dams that change the original flow of the river and block their migration. As a consequence, reduction in downstream fish diversity (Agostinho et al., 2003; Mérona et al., 2005) and even local extinction (Godinho \& Godinho, 1994), mainly of migratory species, are prone to occur in dammed Neotropical rivers. More than 130 major hydroelectric reservoirs (with dams $>10 \mathrm{~m}$ in height) are now in operation in the Upper Paraná River basin, Southeast Brazil (Agostinho et al., 2003).

Around the world, fishways have been built to successfully reconnect migratory routes disrupted by dams (Clay, 1994). Their efficiency in maintaining fish diversity has been under close scrutiny in Brazil (Godinho et al., 1991; Agostinho et al., 2002). Relevant aspects of fish population maintenance in both lower and upper river segments artificially created by dams are frequently neglected in studies judging the convenience of installing such passages (Clay 1994; Agostinho et al., 2002).

The yellow-mandi catfish, Pimelodus maculatus, is a valuable sport and commercial fish in inland waters of Southeast Brazil, reaching maximum standard length of $36 \mathrm{~cm}$ (Lundberg \& Littmann, 2003). As a migratory species, it needs shorter free-flowing stretches of river to spawn than do other Neotropical migrants (Agostinho et al., 2003). During the reproductive season, it leaves Corumbá Reservoir, on the Corumbá River, Centralwest Brazil, to spawn in the main inflowing river (Dei Tos et al., 2002). In the Upper Paraná river basin, its spawning period may extend from a few (Agostinho et al., 2003) to several months (Vazzoler et al., 1997). It is highly fecund (3,200 eggs/g of ova) and the gonadosomatic index averages 5.5, reaching 7.2 (Sato et al., 1999).

In this paper, we evaluated reproductive features, recruitment and the role of the Igarapava Fish Ladder (IFL) on the yellow-mandi fisheries in Igarapava Reservoir.

\section{Material and Methods}

\section{Study area}

The Grande River, one of the tributaries that give rise to the Paraná River, is a tropical plateau river whose headwaters are in the southeastern region of the State of Minas Gerais, at an altitude of $1,250 \mathrm{~m}$, and its mouth is located 1,301 km downstream at the western tip of that state.

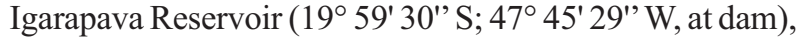
located between the Volta Grande (downstream) and Jaguara (upstream) reservoirs, is one of the 13 hydroelectric reservoirs built in a cascade fashion impounding the Grande River (Fig. 1). Filled in 1998, the reservoir has a surface area of 36.5 $\mathrm{km}^{2}$, with an impounded capacity of $234.5 \times 10^{6} \mathrm{~m}^{3}$. It possesses a few small tributaries, and only a $\sim 5 \mathrm{~km}$ stretch of free-flowing river separates the reservoir from Jaguara Dam upstream.

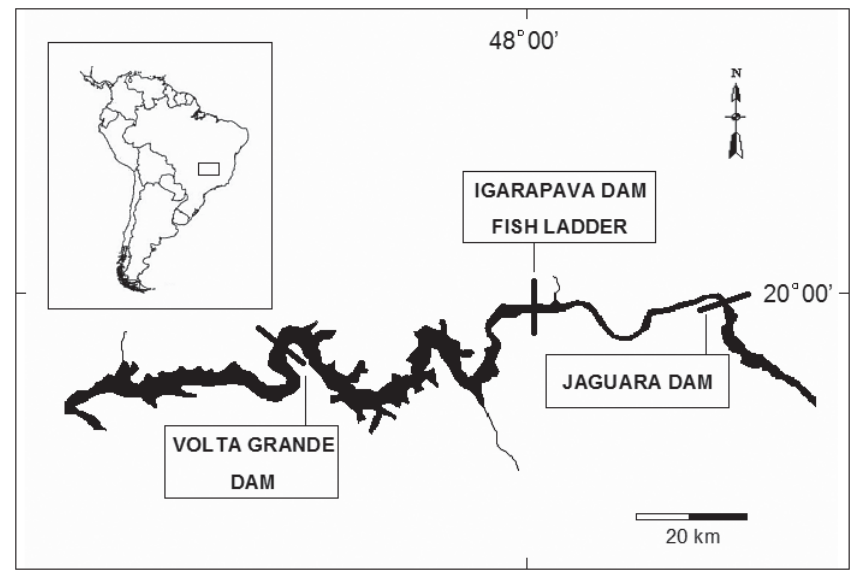

Fig. 1. Study area; location of Volta Grande, Igarapava and Jaguara reservoirs in the Grande River, Southeast Brazil.

The reservoir water level fluctuates less than $1 \mathrm{~m}$ during the year and this greatly limits the reservoir's lateral expansion.

In 1999, a vertical-slot type fish ladder was put into operation alongside Igarapava Dam (http://www.uheigarapava.com.br/; cited: 12 March 2006). It is $17.5-\mathrm{m} \mathrm{high,}$ $282 \mathrm{~m}$-long, with a slope of $6 \%$. It has 87 pools, measuring $3 \mathrm{x}$ $3 \times 3 \mathrm{~m}$ each, interconnected by $40-\mathrm{cm}$ vertical slots with a mean hydraulic head of $19 \mathrm{~cm}$ per slot. An auxiliary water system (attraction flow) located at the ladder entrance was projected to deliver up to $6 \mathrm{~m}^{3} \mathrm{~s}^{-1}$ of water. Range of water velocity at the slot is $1.1-1.9 \mathrm{~m} \mathrm{~s}^{-1}$ (Viana, 2005). A counting window made of transparent acrylic, $1.5-\mathrm{m}$ high and $1.0-\mathrm{m}$ wide, placed near the ladder exit allows visual counts of fish as they exit the ladder.

\section{Adult fish sampling}

We examined female adult Pimelodus maculatus La Cepède, 1803 ( $>21 \mathrm{~cm}$, standard length) from captures made by artisanal fishermen in their regular professional activities in Igarapava Reservoir. We used females captured during three consecutive days in December, 2002 and January and February, 2003, using gill nets of $8 \mathrm{~cm}$ to $20 \mathrm{~cm}$ stretch-mesh. The nets were placed in the middle and distal third of the reservoir in regard to the dam near the mouth of tributaries. They remained in the water column for approximately $15 \mathrm{~h}$, from the afternoon to the next morning; a total $85,845 \mathrm{~m}^{2}$ of nets were used. The following variables were recorded in the field: sex, standard length (SL, to the nearest $\mathrm{cm}$ ), body weight (BW, to the nearest $\mathrm{g}$ ) and ovary weight (OW, to the nearest g). Only the ovaries of each female were kept for histological and fecundity studies. After collecting the data, all carcasses were returned to the fishermen for commercialization. Voucher specimens were deposited in the "Coleção de Peixes do Centro de Transposição de Peixes, Universidade Federal de Minas Gerais (CP/CTP 02/2000-03/2001)."

\section{Ovarian histology}

In the field, fragments of the middle portion of one ovary, randomly selected from each female, were fixed by immersion 
in $5 \%$ glutaraldehyde, buffered with $0.1 \mathrm{M}$ phosphate to $\mathrm{pH}$ 7.3 , for $3 \mathrm{~h}$, kept on ice, washed and maintained in the cold buffer until further processing for histological analyses. In the laboratory, the fragments were re-fixed in Bouin's fixative for $2 \mathrm{~h}$, dehydrated in a graded series of ethanol, and embedded in glycol methacrylate. Sections, $\sim 3 \mu \mathrm{m}$ thick, were stained with $0.5 \%$ toluidine blue solution and viewed using light microscopy.

\section{Female stages of gonadal maturation and gonadosomatic index}

The stages of gonadal maturation of each female were classified as: i) resting, ii) maturation (initial, intermediate and advanced), iii) mature or iv) spawned. The classification was based on gross aspects of the ovaries, on the gonadosomatic index (GSI), in the most advanced phase of oocyte development and in the presence of postovulatory follicles in the ovarian tissue (Wallace \& Selman, 1981; Bazzoli \& Godinho, 1991; Taylor et al., 1998). The following oocyte development phases were described based on histological characteristics common to teleosts (Wallace \& Selman, 1981): i) chromatin nucleolar, in which the scanty cytoplasm is homogeneously basophilic and the centrally located nucleus contains a single, large basophilic nucleolus, ii) perinucleolar, indicated by nucleus enlargement, multiple nucleoli appearance and presence of basophilic, dense material (Balbiani body) in the perinuclear cytoplasm, iii) yolk vesicle, characterized by the appearance of clear cytoplasmic vesicles which increase in size as they move towards the peripheral ooplasm, iv) vitellogenesis, oocytes with central nucleus and whose ooplasm is filled with yolk granules. The gonadosomatic index was calculated as follows: $\mathrm{GSI}=\mathrm{OW} / \mathrm{BW} * 100$.

\section{Fecundity}

Each intact mature ovary of 26 females was transported frozen to the laboratory for fecundity studies. After thawing, each ovary was longitudinally sectioned, and then dipped individually into plastic bottles containing $300 \mathrm{~mL}$ of Gilson's modified fluid (Bagenal, 1978). Weekly, for approximately 10 months, the plastic bottles were gently stirred. Afterward, the hardened vitellogenic oocytes were freed from the ovarian tissue. The remaining partially intact ovarian pieces were then gently broken up with the help of a glass rod. Next, the content of each plastic bottle was poured through a sequence of two metal screens of respectively $500-\mu \mathrm{m}$ and $420-\mu \mathrm{m}$ mesh size, and washed to separate the vitellogenic oocytes from the rest of the disaggregated ovarian tissue. The screen mesh sizes used were chosen after obtaining the diameter of 30 isolated vitellogenic oocytes (oocyte diameter: $567 \pm 42 \mu \mathrm{m}$, range: $456-672 \mu \mathrm{m})$. The oocyte mass now containing only vitellogenic oocytes was oven-dried at $40{ }^{\circ} \mathrm{C}$ for $24 \mathrm{~h}$ and then weighed.

Sub-samples of 20-31 mg of dried vitellogenic oocyte mass from 12 females had their number of vitellogenic oocytes counted. A linear regression equation of oocyte number versus sub-sample mass was then established: $\mathrm{N}=-50.1+23780$
$\mathrm{SM}$; where $\mathrm{N}=$ number of vitellogenic oocytes, $\mathrm{SM}=$ subsample mass, $r^{2}=0.96$. The absolute fecundity (number of vitellogenic oocyte/female) was then estimated using the equation $\mathrm{N}$ for the total weight of the dried vitellogenic oocyte mass. The relative fecundity based on SL, BW and OW was also estimated.

\section{Capture of juveniles}

Gill nets of 3-5 cm stretch-mesh, aimed at capturing juvenile yellow-mandi (Dei Tos et al., 2002), were used in June, 2003, when $0+$ fingerlings would have grown sufficiently to be caught. A total of $1,749 \mathrm{~m}^{2}$ of nets were used. As in the case of adult captures, the nets were placed in the middle and distal third of the reservoir, near tributary mouths, and remained in the water column for approximately $15 \mathrm{~h}$, from the afternoon to the next morning.

\section{Ovarian evaluation of females captured in the IFL}

In order to determine if spawned individuals could reach Igarapava Reservoir through the IFL, we histologically analyzed the ovaries of 71 yellow-mandis previously captured within the IFL from February, 2000 to March, 2002. Fragments of these ovaries were fixed in Bouin's fluid during 4-12 h, dehydrated in a graded series of ethanol and embedded in paraffin. Sections, 5-7 $\mu \mathrm{m}$, were stained with haematoxylineosin and viewed using light microscopy. The occurrence of postovulatory follicles was considered as an indication of recent spawning (Bazzoli \& Godinho, 1991).

\section{Results}

Two-hundred and twenty-six yellow-mandi females captured in Igarapava Reservoir were examined. The number of females used to classify each stage of gonadal maturation and respective morphological characteristics, including ovarian weight, gonadosomatic index and types of oocytes are shown in Table 1.

The distinct ovarian morphology allowed the classification of the stages of gonadal maturation. Ovaries in the resting stage were small in size, exhibiting low GSI. The ovarian size and respective IGS then increased through the different stages to peak at the mature stage. Spawned ovaries were reduced in size. The ovarian color also changed at different stages: purplish at resting, grey during maturation and reddish at spawned.

Ovarian features regarding the presence of different types of oocytes are shown in Fig. 2. Chromatin nucleolar and perinucleolar oocytes, seen in all stages, were the only oocytes observed at the resting stage. The presence of yolk vesicle oocytes indicated the beginning of the maturation stage. Vitellogenic oocytes, which indicated the end of the vitellogenic process, and the presence of postovulatory follicles characterized respectively the mature and spawned stages.

Absolute fecundity of the yellow-mandi was 413,794 \pm 206,259 (range 125,601-742,026); fecundity relative to SL (cm), 
Table 1. Stages of gonadal maturation of the female yellowmandi (Pimelodus maculatus) in Igarapava Reservoir (SGM $=$ stage of gonadal maturation; $\mathrm{n}=$ number of fish analyzed; $\mathrm{OW}=$ ovarian weight, $\mathrm{g}$; GSI = gonadosomatic index).

\begin{tabular}{|c|c|}
\hline SGM & Morphological characteristics \\
\hline 1. Resting & $\begin{array}{l}\text { Pear shaped ovaries, with reduced size, purplish and } \\
\text { translucent; } \\
\mathrm{n}=14 \text {; OW }=3.3 \pm 1.8 \text {; GSI }=0.6 \pm 0.3 \text {; } \\
\text { Histologically, only two types of oocytes were present: } \\
\text { i) chromatin nucleolar }(95 \pm 3 \mu \mathrm{m} \text { in diameter) with } \\
\text { large, vesiculous nucleus }(41.7 \pm 1.2 \mu \mathrm{m} \text { in diameter) } \\
\text { and squamous follicular cells (Fig. } 2 \mathrm{a}, \mathrm{O} 1) \text {; } \\
\text { ii) perinucleolar }(157 \pm 4 \mu \mathrm{m} \text { in diameter) with thin zona } \\
\text { radiata and still paved follicular cells (Fig. } 2 \mathrm{a}, \mathrm{O} 2) \text {; }\end{array}$ \\
\hline 2. Maturation & $\begin{array}{l}\text { Ovaries progressively enlarged; } \\
\text { initial maturation: } \mathrm{n}=15 ; \mathrm{OW}=8.6 \pm 6.4 ; \mathrm{GSI}=2.0 \pm \\
0.9 ; \text { intermediate maturation: } \mathrm{n}=67 ; \mathrm{OW}=28.7 \pm \\
12.2 ; \mathrm{GSI}=5.2 \pm 1.1 ; \text { advanced maturation: } \mathrm{n}=26 \\
\mathrm{OW}=45.2 \pm 19.6 ; \mathrm{GSI}=8.1 \pm 0.8 ; \\
\text { Besides chromatin nucleolar (Fig. } 2 \mathrm{~b}, \mathrm{O} 1 \text { ) and } \\
\text { perinucleolar oocytes (Fig. } 2 \mathrm{~b}, \mathrm{O} 2) \text {, the ovaries had } \\
\text { yolk vesicle oocytes ( } 272 \pm 4 \mu \mathrm{m} \text { in diameter) with } \\
\text { zona radiata thicker than in previous oocytes and } \\
\text { cuboidal follicular cells (Fig. } 2 \mathrm{~b}, \mathrm{O} 3 \text { ); }\end{array}$ \\
\hline 3. Mature & $\begin{array}{l}\text { The ovaries reached their largest size, maintained their } \\
\text { pear shape and were grey in color; } \\
\mathrm{n}=32 \text {; GSI }=12.9 \pm 2.1 \\
\text { They contained chromatin nucleolar (Fig. 2c, O1), } \\
\text { perinucleolar (Fig. } 2 \mathrm{c}, \mathrm{O} 2 \text { ) and vitellogenic ( } 455 \pm 6 \\
\mu \mathrm{m} \text { in diameter) oocytes (Fig. } 2 \mathrm{c}, \mathrm{O} 4) \text {. }\end{array}$ \\
\hline 4. Spawned & $\begin{array}{l}\text { Flaccid ovaries with reduced volume, reddish in color. } \\
\mathrm{n}=72 ; \mathrm{GSI}=3.2 \pm 2.2 \text {. } \\
\text { Histologically, they showed postovulatory follicles (Fig. } \\
\text { 2d, POF) and atresic oocytes (Fig. } 2 \mathrm{~d}, \mathrm{AO} \text { ) together } \\
\text { with all types of the oocytes previously described; in } \\
\text { Fig. 2d only chromatin nucleolar (Fig. 2d, O1) and } \\
\text { perinucleolar (Fig. 2d, O2) are shown. }\end{array}$ \\
\hline
\end{tabular}

to $\mathrm{BW}(\mathrm{g})$ and to $\mathrm{OW}(\mathrm{g})$ was respectively $13,468 \pm 6,201,571$ \pm 192 and 4,420 $\pm 1,202$. Data on linear regression of absolute fecundity versus these variables are in Table 2.

No yellow-mandi juveniles were captured in Igarapava Reservoir. The ovarian histological examination showed the occurrence of postovulatory follicles in $14 \%$ of the females captured in the IFL.

\section{Discussion}

Long-term experimental fish catches have shown that yellow-mandi is the most important species in Igarapava Reservoir fisheries; its population, composed of individuals measuring $>17.5 \mathrm{~cm}$ (standard length), tended to remain relatively constant after three years of age or even increased in the last two years of the study (V. Vono, personal observations). The feasibility of using video technology for estimating and evaluating fish passage was successfully tested at IFL. Thus, it allows us to document and count fish-ladder passage (Bowen et al., 2006). This technology was used by Bizzotto (2006) who collected data in the period of June, 2003 to May, 2004.
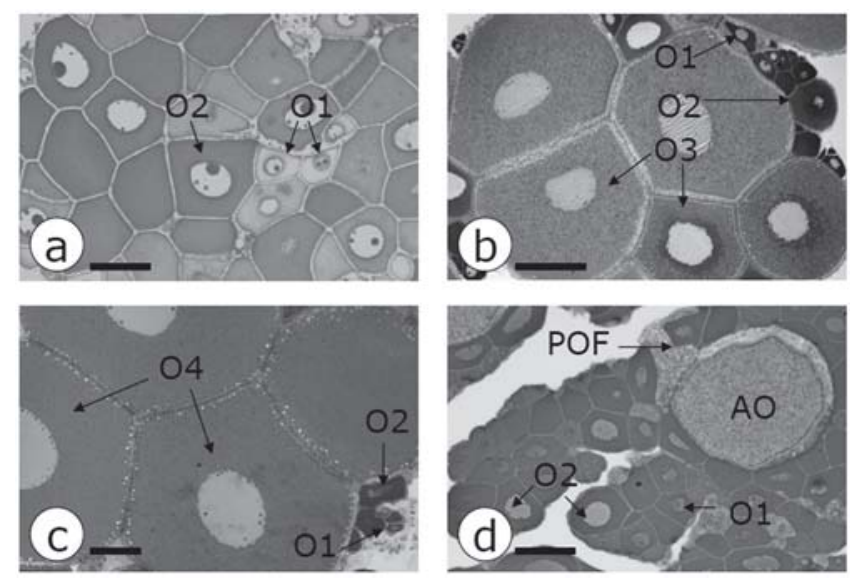

Fig. 2. Histological sections of yellow-mandi ovaries at different stages of gonadal maturation; tissues were fixed in 5\% buffered glutaraldehyde and then post-fixed in Bouin's fluid; bars $=100 \mu \mathrm{m}$. a) Resting stage: chromatin nucleolar (O1) and perinucleolar (O2) were the only types of oocytes present. b) Maturation stage: besides $\mathrm{O} 1$ and $\mathrm{O} 2$ oocytes, the ovary contained yolk vesicle oocytes (O3). c) Mature stage: at this stage the ovaries showed chromatin nucleolar (O1), perinucleolar (O2) and vitellogenic (O4) oocytes. d) Spawned stage: postovulatory follicle (POF) was a striking structure present in the ovaries at this stage; atresic oocyte (AO); chromatin nucleolar $(\mathrm{O} 1)$ and perinucleolar $(\mathrm{O} 2)$ oocytes were also observed.

She demonstrated that adult yellow-mandis ( $33.6 \%$ of the total number of fishes) is the most abundant species in the IFL. The present work confirms the findings of Vono et al. (1997), obtained prior to the construction of Igarapava Dam, which demonstrated that the yellow-mandi was capable of reaching gonadal maturation in the area of the future reservoir.

Combined analyses of ovarian anatomy, histology and GSI of all females studied, allowed us to determine the stages of ovarian maturation of the yellow-mandi. GSI was a good estimate of the reproductive activity as indicated for other Neotropical fishes (Vazzoler, 1996). The presence of mature as well as spawned females in February suggested that the reproductive season in Igarapava Reservoir could have extended beyond the period of study.

Table 2. Linear regression $(Y=a+b X)$ of absolute fecundity $(\mathrm{n}=26)$ versus standard length (SL, cm), body weight (BW, $\mathrm{g})$ and ovarian weight $(\mathrm{OW}, \mathrm{g})$ of yellow-mandis from Igarapava Reservoir; $\mathrm{R}$ = range of variable; $\mathrm{a}=$ regression constant \pm standard deviation; $b=$ regression coefficient \pm standard deviation; $\mathrm{r}^{2}=$ determination coefficient.

\begin{tabular}{ccccc}
\hline Variable & $\mathrm{R}$ & $\mathrm{a}$ & $\mathrm{b}$ & $\mathrm{r}^{2}$ \\
\hline SL & $23.4-34.5$ & $-982084 \pm 378277$ & $46357 \pm 12515$ & 0.34 \\
BW & $300-1050$ & $-130574 \pm 106140$ & $776.4 \pm 146.0$ & 0.52 \\
OW & $42-150$ & $-38349 \pm 65944$ & $4935.9 \pm 674.8$ & 0.68 \\
\hline
\end{tabular}


GSI of our fish specimens was well above that recorded by Sato et al. (1999) and Vono et al. (2002), indicating that females had adequate ovarian development, and consequently, higher fecundity when compared with that of individuals of the same species studied elsewhere (Godinho et al., 1977; Sato et al., 1999). The various oocyte cohorts, including vitellogenic ones, associated with postovulatory follicles characterized the species as group synchronous, batch spawner, as shown earlier by Godinho et al. (1977). The presence of postovulatory follicles in fish ovarian tissue is an indication of recent spawning (Bazzoli \& Godinho, 1991). Possibly, not all spawned females captured in Igarapava Reservoir spawned there since $14 \%$ of the females captured in the IFL exhibited postovulatory follicles indicating that they had already spawned before reaching the reservoir.

Damming of the Grande River has caused a reduction in its fish diversity (Santos \& Formagio, 2000) as seen in other areas of the Upper Paraná River basin (Agostinho et al., 2003). However, the effects of reservoir cascade on the reproduction and recruitment of the yellow-mandi are not well established. Experimental yellow-mandi catches of variable magnitudes have been reported in Grande River reservoirs bearing distinct morphology. They are abundant in reservoirs with extensive catchment area and large tributaries (e.g. Furnas: Santos et al., 1994; Marimbondo: Santos \& Formagio, 2000) as well as in reservoirs with a reduced number of significant tributaries (e.g. Volta Grande: Santos et al., 1994; Santos \& Formagio, 2000).

As the reproduction of Neotropical migratory fish occurs during the rainy season, its small and buoyant eggs or larvae are passively driven to downstream floodplains where they accomplish their initial period of life (Agostinho et al., 2003). The yellow-mandi in our work had reached full ovarian maturation, as indicated by the high GSI and fecundity, as well as possibly spawned in the reservoir area. However, the lack of juveniles in gill nets, appropriate for capturing them (Dei Tos et al., 2002), as V. Vono (pers. observ.) has recorded, was an indication that the area did not provide adequate conditions, functional floodplains for example, for yellow-mandi recruitment.

Recent radiotelemetry experiments have shown that less than $22 \%$ of the yellow-mandis that were captured in the IFL, tagged and then released in Igarapava Reservoir, returned via turbines to the downstream Volta Grande reservoir (Silva, 2004). As there is no passage mechanism allowing fish to move upstream from Igarapava Reservoir, most of the yellowmandi that reached the reservoir tended to remain there.

In conclusion, the yellow-mandi apparently was able to spawn in Igarapava Reservoir. However, the unsuccessful effort to capture juveniles was a strong indication that recruitment in the reservoir area was absent. Although a small proportion of yellow-mandis might have returned downstream, the majority of those reaching the reservoir through the IFL possibly remained there. Thus, Igarapava yellow-mandi fisheries was shown to be heavily dependent on the upstream passage of Volta Grande fish through the IFL.

\section{Acknowledgements}

We thank the Brazilian CNPq/CT-Hidro (Project no. 521259/ 01-0) for the financial support and also the Igarapava Hydroelectric Consortium for allowing us to collect fish at the IFL.

\section{Literature Cited}

Agostinho, A. A., L. C. Gomes, D. R. Fernandez \& H. I. Suzuki. 2002. Efficiency of fish ladder for Neotropical ichthyofauna. River Research and Application, 18: 299-306.

Agostinho, A. A., L. C. Gomes, H. I. Suzuki \& H. F. Júlio Jr. 2003. Migratory fishes of the Upper Paraná river basin, Brazil. Pp. 19-98. In: Carolsfeld, Y., B. Harvey, C. Ross, \& A. Baer (Eds.). Migratory fishes of South America: biology, fisheries and conservation status. Ottawa, International Development Centre/ The World Bank, 372p.

Bagenal, T. 1978. Methods for assessment of fish production in fresh waters. Oxford, IBP Handbook n³, Blackwell Scientific Publications, 365p.

Bazzoli, N. \& H. P. Godinho. 1991. Reproductive biology of the Acestrorhynchus lacustris (Reinhardt, 1874) (Pisces: Characidae) from Três Marias Reservoir, Brazil. Zoologischer Anzeiger, 226: 285-297.

Bizzotto, P. M. 2006. Trânsito de peixes na escada da UHEIgarapava, Rio Grande, Alto Paraná. Unpublished Master Thesis, Pontifícia Universidade Católica de Minas Gerais, Belo Horizonte. 52p.

Bowen, M. D., S. Marques, L. G. M. Silva, V. Vono \& H. P. Godinho. 2006. Comparing on site human and video counts at Igarapava fish ladder, Southeastern Brazil. Neotropical Ichthyology, 4(2): 291-294.

Carolsfeld, Y. \& B. Harvey. 2003. Introduction: fishes of the floods. Pp. 1-18. In: Carolsfeld, Y., B. Harvey, C. Ross \& A. Baer (Eds.). Migratory fishes of South America: biology, fisheries and conservation status. Ottawa, International Development Centre/The World Bank, 372p.

Clay, C. H. 1994. Design of fishways and other fish facilities. Boca Raton, CRC Press, 248p.

Dei Tos, C., G. Barbieri, A. A. Agostinho, L. C. Gomes \& H. I. Suzuki. 2002. Ecology of Pimelodus maculatus (Siluriformes) in the Corumbá reservoir, Brazil. Cybium, 26: 275-282.

Godinho, A. L. \& H. P. Godinho. 1994. Ecology and conservation of fish in Southeastern Brazilian river basins submitted to hydroelectric impoundments. Acta Limnologica Brasiliensia, 5: 187-197.

Godinho, H. M., M. A. Basile-Martins, N. A. Fenerich \& N. Y. Narahara. 1977. Fecundidade e tipo de desova do mandi, Pimelodus maculatus Lacépède, 1803 (Pisces, Siluroidei). Revista Brasileira de Biologia, 37: 737-744.

Godinho, H. P., A. L. Godinho, P. S. Formagio \& V. C. Torquato, 1991. Fish ladder efficiency in a South-eastern Brazilian river. Ciência e Cultura, 43: 63-67.

Lundberg, J. G. \& M. W. Littmann. 2003. Pimelodidae (longwhiskered catfishes). Pp. 432-446. In: Reis, R. E., S. O. Kullander \& C. J. Ferraris Jr. (Eds.) Checklist of the freshwater fishes of South and Central America. Porto Alegre, Edipucrs, 729p.

Mérona, B., R. Vigouroux \& F. L Tejerina-Garro. 2005. Alteration of fish diversity downstream from Petit-Saut Dam in French Guiana: implication of ecological strategies of fish species. Hydrobiologia, 551: 33-47. 
Santos, G. B., P. M. Maia-Barbosa, F. Vieira \& C. M. López. 1994. Fish and zooplankton community structures in reservoirs of South-eastern Brazil: effects of the introduction of exotic predatory fish. Pp.115-132. In: Pinto-Coelho, R. M., A. Giani, \& E. Sperling (Eds.). Ecology and human impact on lakes and reservoirs in Minas Gerais with special reference to future development and management strategies. Belo Horizonte, Segrac, 193p.

Santos, G. B. \& P. S. Formagio. 2000. Estrutura da ictiofauna dos reservatórios do rio Grande, com ênfase no estabelecimento de peixes piscívoros exóticos. Informe Agropecuário, Belo Horizonte, 21: 98-106.

Sato, Y., N. Fenerich-Verani, J. R. Verani, H. P. Godinho \& E. V. Sampaio. 1999. Reproductive traits of yellow-mandi catfish Pimelodus maculatus Lacépède (Osteichthyes, Siluriformes) in captive breeding. Revista Brasileira de Zoologia, 16: 981-986.

Silva, L. G. M. 2004. Deslocamentos de mandis-amarelos e curimbas em dois reservatórios do rio Grande, bacia do alto Paraná. Unpublished Master Thesis. Pontifícia Universidade Católica de Minas Gerais, Belo Horizonte. 73p.

Taylor, R. G., H. J. Grier \& J. A. Whittington. 1998. Spawning rhythms of common snook in Florida. Journal of Fish Biology, 53: 502-520

Vazzoler, A. E. A. M. 1996. Biologia da reprodução de peixes teleósteos: teoria e prática. Maringá, Eduem, 169p.
Vazzoler, A. E. A. M., H. I. Suzuki, E. E. Marques \& M. A. P. Lizama. 1997. Primeira maturação gonadal, períodos e áreas de reprodução. Pp. 249-266. In: Vazzoler, A. E. A. M., A. A. Agostinho \& N. S. Hahn (Eds.). A planície de inundação do alto rio Paraná: aspectos físicos, biológicos e socieconômicos. Maringá, Eduem, 460p.

Viana, E. M. F. 2005. Mapeamento do campo de velocidades em mecanismos de transposição de peixes do tipo ranhura vertical em diferentes escalas. Unpublished Ph.D. Dissertation, Universidade Federal de Minas Gerais, Belo Horizonte. 226p.

Vono, V., C. B. M. Alves \& A. L. B. Magalhães. 1997. A ictiofauna dos cursos d'água tributários do reservatório da futura UHEIgarapava - Rio Grande. Acta Limnologica Brasiliensia, 9: 3343.

Vono, V., L. G. M. Silva, B. P. Maia \& H. P. Godinho. 2002. Biologia reprodutiva de três espécies simpátricas de peixes neotropicais: Pimelodus maculatus (Siluriformes, Pimelodidae), Leporinus amblyrhynchus e Schizodon nasutus (Characiformes, Anostomidae) no recém-formado reservatório de Miranda, Alto Paraná. Revista Brasileira de Zoologia, 19: 819-826.

Wallace, R. A. \& K. Selman. 1981. Cellular and dynamic aspects of oocyte growth in teleosts. American Zoologist, 21: 325-343.

Received January 2007 Accepted May 2007 